\title{
HUBUNGAN BISING DENGAN GANGGUAN PENDENGARAN PADA PEKERJA GAME CENTRAL AREA DI AREA MANADO TRADE CENTER
}

\author{
${ }^{1}$ Ria M. Rantung \\ ${ }^{2}$ Fransiska Lintong \\ ${ }^{2}$ Vennetia R. Danes \\ ${ }^{1}$ Kandidat Skripsi Fakultas Kedokteran Universitas Sam Ratulangi Manado \\ ${ }^{2}$ Bagian Fisika Fakultas Kedokteran Universitas Sam Ratulangi Manado \\ Email: rrantung11_201@yahoo.com
}

\begin{abstract}
Noise is commonly found in work areas. The facilities used in the Game Centers such as speakers in large numbers cause noise that directly affects workers and other people who are in the area of Game Center in the forms of communication disorder, impaired concentration, and impaired hearing comfort. This study aimed to determine the relationship of noise and hearing disorders among workers of Games Central Area in Manado Trade Center (MTC). This was an analytical observational study with a cross-sectional design. Respondents were 20 workers in Game Central Area MTC who filled the informed consent, questionnaires, and fulfilled the inclusion and exclusion criteria. Data were statistically analyzed by using Chi-square test with SPSS. The results showed that of the 20 respondents, there were 3 (15\%) with hearing loss, 2 (10\%) with mild deafness, and $1(5 \%)$ with moderate deafness. The chi-square test showed that there was a significant relationship between the level of noise and hearing disorders in the left and right ears with a p-value $0.002<\alpha=0.05$. Conclusion: There was a signicant relationship between the level of noise and hearing disorders among workers of Games Central Area in Manado Trade Center.
\end{abstract}

Keywords: noise, hearing loss

\begin{abstract}
Abstrak: Kebisingan merupakan salah satu faktor yang tidak luput dari lingkungan pekerjaan. Fasilitas yang digunakan dalam Game Center seperti speaker dalam jumlah banyak menimbulkan bising yang berpengaruh langsung pada tenaga kerja maupun orang lain yang berada di area tersebut yaitu berupa gangguan komunikasi, gangguan konsentrasi, dan gangguan kenyamanan pendengaran. Penelitian ini bertujuan untuk mengetahui hubungan kebisingan dan gangguan pendengaran pada pekerja Game Central Area di Manado Trade Center (MTC). Penelitian ini menggunakan metode observasional analitik dengan desain potong lintang. Responden ialah 20 pekerja Game Central Area MTC yang bersedia mengisi informed consent, kusioner, serta dipilih berdasarkan kriteria inklusi dan eksklusi. Analisis data dilakukan dengan uji statistik Chi-square dengan menggunakan SPSS. Hasil penelitian menunjukkan, dari 20 responden terdapat 3 orang (15\%) mengalami gangguan pendengaran, 2 orang (10\%) tuli ringan, dan 1 orang (5\%) tuli sedang. Hasil analisis bivariat dengan uji Chisquare mendapatkan adanya hubungan bermakna antara tingkat kebisingan dan gangguan pendengaran baik pada telinga kiri maupun kanan dengan nilai $p=0,002<\alpha=0,05$. Simpulan: Terdapat hubungan bermakna antara tingkat kebisingan dengan gangguan pendengaran baik pada telinga kiri maupun kanan pada pekerja Game Central Area di Manado Trade Center.
\end{abstract}

Kata kunci: bising, gangguan pendengaran 
Industri game telah menjadi salah satu lini bisnis yang sangat menguntungkan. Hal ini mempengaruhi pertumbuhan industri game di Indonesia yang mengalami perkembangan yang cukup signifikan.Ini ditandai dengan semakin meningkatnya pemain game (gamers). Setiap tahun jumlah pemain game di Indonesia terus menerus bertambah, bahkan saat ini Indonesia mengalami pertumbuhan pemain game hingga 33\%. Gamers tidak diharuskan memiliki personal computer (PC) ataupun konsol (video game) untuk bermain game. Gamers hanya perlu menyambangi game center berfasilitas game online yang kini sudah sangat jamak tersebar di banyak tempat. $^{1}$

Fasilitas yang digunakan dalam Game Center seperti speaker dalam jumlah yang banyak menimbulkan bising yang berpengaruh langsung pada tenanga kerja maupun orang lain yang berada di area Game Center, yaitu berupa gangguan komunikasi, gangguan konsentrasi, gangguan kenyamanan pendengaran. Gangguan seperti ini akan dirasakan para tenaga kerja pada setiap melakukan pekerjaan sehingga akan dapat menimbulkan ketidaknyamanan kerja. ${ }^{1}$

Kebisingan merupakan salah satu faktor yang tidak luput dari lingkungan pekerjaan. Pendengaran akibat terpapar suara yang bising atau Noise Induced Hearing Loss (NIHL) merupakan salah satu penyakit akibat kerja paling banyak dijumpai di lingkungan kerja. ${ }^{2}$ Noise Induced Hearing Loss dalam bahasa Indonesia disebut Tuli Akibat Bising (TAB). TAB adalah suatu kelainan atau gangguan pendengaran berupa penurunan fungsi indera pendengaran akibat terpapar oleh bising dengan intensitas yang berlebih terus-menerus dalam waktu lama. ${ }^{3}$

Kebisingan selain dapat menimbulkan ketulian sementara dan ketulian permanen juga akan berdampak negatif lain seperti gangguan komunikasi, efek pada pekerjaan dan reaksi masyarakat. Apabila bekerja dengan kondisi tidak nyaman lama kelamaan akan menimbulkan stres dan kelelahan. $^{4}$
Menurut WHO-SEARO (South East Asia Regional Office) Intercountry Meeting (Colombo, 2002) faktor penyebab gangguan pendengaran adalah otitis media suppuratif kronik (OMSK), tuli sejak lahir, pemakaian obat ototoksik, pemaparan bising, dan serumen prop. ${ }^{5}$

Penelitian yang dilakukan oleh Maliya mengenai efek kebisingan pada 42 pekerja penggilingan padi di wilayah Colomadu, Karanganyar mendapatkan bahwa intensitas bising mesin pengggilingan padi mayoritas mempunyai $\mathrm{NAB}>85 \mathrm{~dB}$ yang melebihi NAB telinga manusia. Responden mengalami gangguan fungsi pendengaran berupa tuli ringan dengan tingkat ketulian 26-40 dB dan tuli sedang dengan tingkat ketulian 41-60 dB. ${ }^{3}$

\section{METODE PENELITIAN}

Penelitian ini menggunakan metode observasional analitik dengan desain potong lintang yang dilakukan pada bulan Oktober sampai dengan Desember 2014, bertempat di Game Central Area Manado Trade Center. Sasaran populasi penelitian ini ialah 20 orang pekerja Game Central Area di Manado Trade Center yang dipilih berdasarkan kriteria inklusi dan ekslusi. Pekerja yang mengikuti penelitian bersedia mengisi kuisioner dan informed concent.

Pada penelitian ini yang menjadi variabel bebas ialah bising dan variabel terikat ialah gangguan pendengaran. Intrumen penelitian yang digunakan berupa kuisioner penelitian, Sound Level Meter, dan audiometer.

\section{HASIL PENELITIAN}

Tabel 1. Distribusi Responden berdasarkan usia

\begin{tabular}{ccc}
\hline Usia (tahun) & $\mathrm{n}$ & $(\%)$ \\
\hline$<20$ & 3 & 15 \\
$20-30$ & 16 & 80 \\
$>30$ & 1 & 5 \\
Jumlah & 20 & 100,0 \\
\hline
\end{tabular}


Tabel 2. Distribusi responden berdasarkan jenis kelamin

\begin{tabular}{ccc}
\hline Jenis Kelamin & n & $(\%)$ \\
\hline Laki-laki & 15 & 75 \\
Perempuan & 5 & 25 \\
Jumlah & 20 & 100,0 \\
\hline
\end{tabular}

Tabel 3. Distribusi responden berdasarkan tingkat kebisingan

\begin{tabular}{ccc}
\hline $\begin{array}{c}\text { Tingkat Kebisingan } \\
(\mathrm{dB})\end{array}$ & $\mathrm{n}$ & $\mathbf{( \% )}$ \\
\hline 85 & 17 & 85 \\
89 & 3 & 15 \\
Jumlah & 100 & 100,0 \\
\hline
\end{tabular}

Tabel 4. Hasil analisis dengan menggunakan uji chi-square

\begin{tabular}{cc}
\hline $\begin{array}{c}\text { Tingkat } \\
\text { kebisingan }\end{array}$ & $\begin{array}{c}\text { Asymp. Sig. } \\
(2 \text {-sided) }\end{array}$ \\
\hline Telinga kanan &, 002 \\
Telinga kiri &, 002 \\
\hline
\end{tabular}

\section{BAHASAN}

Berdasarkan hasil analisis univariat didapatkan bahwa responden penelitian terbagi menjadi 3 kelompok usia yaitu usia 20-30 tahun, <20 tahun dan >30 tahun. Usia terbanyak terdapat pada kelompok usia 20-30 tahun dengan jumlah 16 orang (80\%), sedangkan kelompok usia terendah yaitu usia $>30$ tahun yang berjumlah 1 orang (5\%). Untuk jenis kelamin, responden terbanyak yaitu laki-laki dengan jumlah 15 orang (75\%) sedangkan perempuan hanya berjumlah 5 orang (5\%).

Nilai Ambang Batas (NAB) kebisingan di tempat kerja berdasarkan Keputusan Menteri Tenaga Kerja No. Kep.51/MEN/1999 yang merupakan pembaharuan dari Surat Edaran Menteri Tenaga Kerja No. 01/MEN/1978, besarnya rata-rata ialah $85 \mathrm{~dB}(\mathrm{~A})$ untuk waktu kerja terus-menerus tidak lebih dari 8 jam/hari atau 40 jam selama satu minggu. ${ }^{6}$

Pembagian gangguan pendengaran berdasarkan tingkatan beratnya gangguan pendengaran, yaitu mulai dari gangguan pendengaran ringan (20-40 dB), gangguan pendengaran sedang $(40-60 \mathrm{~dB})$, dan gangguan pendengaran berat $(60-80 \mathrm{~dB}){ }^{7}$

Berdasarkan hasil analisis bivariat dengan menggunakan uji Chi-square (Tabel 4) didapatkan adanya hubungan bermakna antara tingkat kebisingan dengan gangguan pendengaran baik pada telinga kiri maupun pada telinga kanan dengan nilai $\mathrm{p}=0,002<\alpha=0,05$. Hal ini sejalan dengan penelitian yang dilakukan oleh Syamsiar dan Russeng terhadap pekerja di unit produksi paving block CV. Sumber Galian Makasar dimana didapatkan kebisingan dengan gangguan pendengaran yang signifikan $(\mathrm{p}<0,001){ }^{8} \quad$ Penelitian yang dilakukan oleh Yakub dari Fakultas Kesehatan Masyarakat Universitas Diponegoro terhadap perbedaan ambang pendengaran tenaga kerja sebelum dan sesudah bekerja pada intensitas kebisingan di atas NAB di Pabrik Batako U.D. Berkat di Kabupaten Dili didapatkan gangguan pendengaran bermakna dengan $(p<0,001) .{ }^{9}$

\section{SIMPULAN}

Berdasarkan hasil penelitian terhadap pekerja di Game Central Area Manado Trade Center didapatkan adanya hubungan bermakna antara tingkat kebisingan dan gangguan pendengaran.

\section{SARAN}

1. Menggunakan alat pelindung telinga agar mengurangi kemungkinan terjadinya gangguan pendengaran

2. Perlu penelitian lebih lanjut dengan jumlah responden yang lebih besar untuk mendapatkan pengaruh faktor pencetus lainnya

\section{DAFTAR PUSTAKA}

1. Wijayanti TW. Motif dan adiksi pemain game online (studi deskriptif tentang motif dan adiksi pemain game online dragon nest di Surabaya). Journal Universitas Airlangga. 2013;2(1).

2. Tri Budiyanto T, Pratiwi EY. Hubungan Kebisingan Dan Massa Kerja Terhadap Terjadinya Stres Kerja Pada Pekerja di Bagian Tenun Agung Saputra Tex Piyungan Bantul Yogyakarta [Skripsi]. Yogyakarta: Universitas Ahmad Dahlan; 2011. 
3. Lianasari C. Hubungan antara kebisingan dengan fungsi pendengaran pada pekerja penggilingan padi di Colomadu Karanganyar [Skripsi]. Surakarta: Universitas Muhammadiyah; 2010.

4. Mursali A, Basuki E, Dharmono S. Relationship Between Noise and Job Stress at a Private Thread Spinning Company. Univ Med. 2009;28:8-16.

5. Susanto. Risiko gangnguan pendengaran pada neonatus hiperbilirubinemia [Tesis]. Semarang: Universitas Diponegoro; 2010.

6. Ummi Ianatul Khakim. Hubungan Masa Kerja Dengan Nilai Ambang Dengar tenaga Kerja Yang Terpapar Bising Pada Bagian Weaving di PT. Triangga dewi Surakarta [Skripsi]. Surakarta: Universitas Sebelas Maret,
2011.

7. Workplace health and safety Queensland. Managing Noise and Preventing Hearing Loss. Code of Practice. NSW government; 2011.

8. Hisma S. Hubungan Kebisingan dan Gangguan Pendengaran pada Pekerja di Unit Produksi Paving Block CV. Sumber Galian Makasar [Tesis]. Makasar: Universitas Hassanuddin, 2011.

9. Ardanariswari, et al. Perbedaan Ambang Pendengaran Tenaga Kerja Sebelum dan Sesudah bekerja pada Intensitas Kebisingan di atas Nilai Ambang Batas (NAB) di Pabrik Batako UD. Berkat Kabupaten Dili [Skripsi]. Semarang: Universitas Diponegoro, 2012. 